\title{
Perspectives on Families and Parenting in Early Years: A Critical Review of Evidence in Policy and Curriculum Documents
}

\author{
Sevim KARAOĞLU'
}

\begin{abstract}
This critical review has sought to examine the parental provision in the Turkish policy and early childhood curriculum. It has been vehemently acknowledged by literature and policy documents in overall the world that the role of parents play as principal educators of their children has also been highlighted. Family have significant roles for their children's development as providing atmosphere during early years. In fact, there has been a volume of studies and policy documents that have put an emphasis on the diversity of parents' role on children's development in their early years period. However, there is limited inclusion of approaches to support children's learning and development practiced by families within educational context. Therefore, this critical review aimed to locate the national and international research and documentary evidence relating to parenthood in the early years sector within wide-ranging search and Turkish policy documents. This review brings to life the theories about the benefits and importance of parenthood implications and issues and will help illustrate how practice can affect children either positively and negatively.
\end{abstract}

Keywords: Early Childhood, Early Years Policy Document, Curriculum, Family Involvement, Parenthood

\section{Erken Çocukluk Eğitim Müfredatı ve İlgili Dokümanlar Kapsamında Aile ve Ebeveynliğe Eleştirel Bir Bakış}

Öz: Bu derleme çalışması Türkiye'deki erken çocukluk eğitim politikasında ve müfredatında belirtilen ebeveynlerin eğitimdeki konumunu incelemektedir. Evrensel olarak alan yazında ve eğitim politikaları dokümanlarında ebeveynlerin çocuklarının asıl öğretmenleri olarak önemli rolleri olduğu vurgulanmıştır. Çocukların gelişimlerinin doğumla başlaması, erken yaşlarında ise ev ve aile ortamındaki olumlu bir atmosfer ortamında devam etmesi beklenmektedir. Aslında, erken çocukluk döneminde ebeveynlerin çocuğun gelişimindeki çeşitli rollerini vurgulayan pek çok çalışma ve doküman mevcuttur. Ancak, bu dönemde eğitim bağlamında ebeveynlerin çocuklarının öğrenmelerini ve gelişimlerini desteklemeleri bu çalışmalarda sınırlı bir şekilde ele alınmıştır. Bu yüzden, bu derleme çalışmasında Türkiye'deki erken çocukluk eğitim müfredatında ve ilgili dokümanlarında belirtilen ebeveynlerin eğitimdeki konumu, ulusal ve uluslararası araştırmalar ve dokümanlar dikkate alınarak daha geniş bir kapsamda tartışlacaktır. Böylelikle, bu çalışma çocukların öğrenme ve gelişimlerini desteklemesi bağlamında ebeveynliğin faydası ve önemi ile ilgili kuramsal çerçevede ebeveynlerin problemlerini ve çocukların üzerindeki olumlu ve olumsuz etkilerini ortaya koyacaktır.

Anahtar Sözcükler: Erken Çocukluk Dönemi, Erken Yaş Dokümanları, Müfredat, Aile Katılımı, Ebeveynlik 
Policy documents in Turkey such as government supported organisations, state universities' organisations, the Ministry of National Education's reports and the Council of National Education (CNE)'s decisions over the past fifty years have stated that partnerships with parents and families have become increasingly important in educational settings (CNE, 1946, 1974, 1982, 1988, 1993, 1996, 2010; Milli Egitim Bakanligi [MEB], 1994, 2002, 2006, 2013). These policy documents and government supported organisations' reports and programs are aimed at developing the ability of Turkish early childhood education system to parent's parenting skills through political and educational programmes. For instance, the Mother-Child Education Foundation (Anne Cocuk Egitim Vakfi [ACEV]), which is supported by the Ministry of Education, has stated that children's cognitive, verbal and numeric ability and development might be supported by parents in order to improve school readiness in the early years, as evidenced by their Parent-Young Children Education project which started in 1999 and is still continuing. The project is being carried out in liaison with the Ministry of National Education Basic Education Department and its results have demonstrated that due to the project children's learning has constantly has been improved (ACEV, 1999). There are also training guides for families, Family Support and Education Guidebook Integrated with Pre-school Education Programme (OBEDER) and Family Support and Education Guidebook Integrated with 0-3-year-old Children's Education (EBADER). These guides were developed by Turkish Ministry of Education under the professional assistance of United Nations International Children's Emergency Fund (UNICEF) and the fund of European Union in a responsibility of Strengthening Pre-School Education Project in 2013. OBADER is a guide integrated with the Pre-school Education Curriculum which leads the way of family involvement in the educational settings. EBADER is another guide integrated with only 0-3 years period's education practice. EBADER has some learning materials to teach implementation for supporting children's education in home environment. In light of these kinds of results and programmes, parents are recognised as the first educators of their children and play a crucial role in their children's development (Organisation for Economic Co-operation and Development [OECD], 2012).

Siraj-Blatchford (1998) has asserted that children's future academic success could be improved with long term support from parents. Parental involvement which includes the interplay of parents and children helps the development of children, children's school readiness and has long term effects (Pelletier and Brent, 2002). ACEV has revealed that families and parenting are fundamental for promoting a good quality and healthy early childhood (ACEV, 2011). Besides these important potential contributions, parental partnership in the early years is hard to implement in practice at school because of issues such as early childhood educator attitudes, gaps in the policy and curriculum. Gol-Guven (2009) found that teachers who work in the Turkish public preschools usually reduce parents' encouragement in education and meeting with parents twice in a year is seen as enough to arrange parental involvement. In this paper, it will be discussed that the interactions of early childhood educators and parents alongside current Turkish early childhood policy and Turkish Preschool Education Curriculum (TPSEC), which needs to be improved in order for early childhood educators to have effective relationships with parents.

Despite the importance of family involvement in early childhood education, early childhood educators need to improve their work with parents and assure parents of the advantages of partnership with them in the early years. Strong parental encouragement may produce better performance at school (Central Advisory Council of England [CACE], 1967). This review begins by evaluating the understanding and concept of partnership with parents and families, what it includes and how it could be used to greater advantage in the current context of early years' reports, programmes and curriculum development in Turkey. This is followed by an examination of various barriers to parental partnerships and family involvement which are influenced by society, early childhood educators and policies. Thereafter, the implications for parenthood as derived from recent policies and curricula will be evaluated. Finally, the review looks at how understandings of parental partnerships and family involvement could be developed effectively by early childhood educators in the light of recent policy and curricula. 


\section{Family involvement and parental partnership in the early years}

Parental interaction is an intrinsic value and an on-going process in children's social and academic life (Davis, Day, and Bidmead, 2002). A good relationship between early childhood educator and parents is fundamental to the learning and development process in Early Years Education (EYE). Allen (2011, p.57) emphasizes that 'the early home environment is the single biggest influence on a child's development, and it is more important than material circumstance or parental income, occupation or education'. In line with this, parents are the first and most important educators in their children's life and are the first nurturers and socialisers (Berger, 2004). Nurturing and supporting their children's social and emotional development is generally recognised to be parents' responsibility throughout EYE (Davis et al., 2002). Early Years Foundation Stage in 2012, convincingly argues that parents are children's first and enduring educators (EYFS, 2012). When parents and early childhood educators work together in the early years settings, the results have a positive impact on children's development and learning (Department for Education, 2017). Therefore, getting to know parents as people with different backgrounds and views which influence their children's everyday activities could be helpful for children's learning and development practices and also improving relationships with early childhood educators and parents (Siraj-Blatchford, 1998). However, parental partnership in Turkish EYE settings is insufficient at the moment. It is not enough to provide parental involvement in the early years via meeting twice times in a year and it is accepted by pre-school teachers that limited interaction with parents is easiness in the school (Divrengi and Aktan, 2011; Gol-Guven, 2009). At this point, Kaya's (2007, p. 47) suggestion that "parents and teachers could work together because both have same goal: to educate the children and bring them up to be more responsible people for the society" could be a useful consideration to encourage great awareness and debate on the issue in a Turkish context. From the perspective of educators, Hakyemez (2015) found that there are positive thoughts about parental involvement models, especially, homesupport family involvement is the popular one.

Interaction between parents and children provides children with the first step to becoming socially aware and acquiring social skills (Tezel Sahin and Ozyurek, 2010). Family culture is important that surround their children life and play a role on them with emotionally, physically and historically (Vygotsky, 1978). In accordance with Vygotsky's ideas explained that the relationship between home and educational setting is necessary and recommends that if there is a lack of communication between home and school, the necessity could be waste and the effort presented for children's development can be confusing (Rogoff, 1990). Within this point, Vygotsky highlighted that when children are interacting with their social environment, learning disposition awakens (Holzman, 2009). The social environment plays a crucial role in learning and development in early years, a fact underlined by the Zone of Proximal Development, defined by Vygotsky as "difference between 'actual developmental level as determined by independent problem solving' and 'the level of potential development as determined through problem solving under adult guidance or in collaboration with more capable peers'" (Vygotsky, 1978, p. 86). Therefore, the relationship between early childhood educators and parents is an essential one in order to provide children with more effective and highquality learning in the early years. Davis argues that if early childhood educators want to supply useful help for parents and for their children, they need to understand the nature of this relationship (Davis et al., 2002).

Pupils show better skills in reading and learning when their parents are involved in their education, as outlined in the OECD's study "Let's read them a story!". The parent factor in education, which aims to provide a corrective to the idea that some parents have that their contribution to their young children's education stops when their formal schooling begins (OECD, 2012). In particular, this OECD Programme for International Student Assessment report argues for the crucial role of parents in developing their children's proficiency and enjoyment of reading. EYE, the provision of educational setting in the home or educating parents has positively affected the academic achievement of children at school (Sy, Gottfried and Gottfried, 2013). In this way, we can underline the necessity of students' development of learning skills which needs to be effectively developed in the school, but also by parents and the wider community. Therefore, this is an important point to emphasise in the policy and curriculum document such as the Turkish Education Organisation. The organisation is supported by the Turkish government for research has found that educated and high socio- 
economic level parents are more willing to support parental partnership with early childhood educators when compared with low socio-economic level parents. It is important to support parents who live in low socioeconomic conditions in child development, early childhood education and child rearing (Turk Egitim Dernegi [TED], 2007). For this reason, policy-makers and educators need to focus on socio-economic perspectives in the society when they are developing policies or mandates about the role of parenthood in education. This is the mutual responsibility of families, educators and the variety of institutions in the policy and in the society (OECD, 2012). According to the ACEV (2011) although parent-child-teacher interaction is a dynamic process in EYE, it is hard to reconcile the conflicts between parents' and early childhood educators' relationships. In devising a parental involvement programme, it should be paramount that parents are given opportunities to express their ideas about the current pre-school programme and are given a certain reciprocal respect. The Turkish Pre-school Education Curriculum supports parental involvement (MEB, 1994, 2006). Parents and early childhood educators' collaboration in preschool institutions have a great importance with regard to children settling in easily to school, and this has been acknowledged in the Turkish academic literature on educational issues related to children between the ages of 5 and 6 (Omeroglu and Can Yasar, 2005; Oneren Sendil and Tantekin Erden, 2013; Unusan and Sanlier, 2007). Early childhood educators should be given house-training programmes to inform parents on how children's development can be provided and supported within high standards in social development, social competence and other developmental areas at their home (Ogelman and Seven, 2012). Additionally, the mutually complementary qualification of parents and early childhood educators have the potential to prevent the development of negative attitudes to the child in the home and school environment and multi- directional contribution of this collaboration can provide healthy child development and adapting to school (Isik, 2007).

The "Pre-school Teacher Adequacy of Domain" which was prepared in 2008 by the National Ministry of Education in Turkey as a part of PSEC teacher responsibilities section stated that encouragement of parent involvement is a part of EYE progress and it must be taken into account by teachers (ACEV, 2011). The document states that developing a close relationship between families and the school means that the child is identified as a member of a family and a local society, therefore children's performance as students is influenced by their life outside of the school as well as inside it, this emphasising the potential role of parents (Vincent, 2012). There are some issues such as limited communication with parents, teachers' reluctance and lack of supporting family involvement policy and curriculum document (Kaya, 2007; Ozyurek, 2004; TED, 2007; Tokuc, 2007; UNICEF, 2011). The context of The Turkish Pre-school Education Curriculum is combined with the quality of children's development, care, family background and especially parental beliefs and therefore these elements shaped the value of EYE and how it might be acquired (Bekman, 2002).

\section{Issues relating to parental partnerships in the early years}

Parental partnership involves not only mothers but also fathers in the contemporary educational context. A longstanding debate has also been concerned with the responsibilities of mothers and their active role in child-rearing, which has continued to very recently (Vincent, 2012). Correspondingly, the employment of women and children's care is required to develop of the politics in the EYE and care institutions (Bogazici University [BU], 2009). For many decades, women's role in business and in the workforce and the prominence of female entrepreneurs has increased in Turkish society (TED, 2007). The number of working women has gradually increased because of industrial revolution and technological changes after the second half of the 20th century (Tokuc, 2007). Mothers generally are positioned as holding the principal responsibility for childrearing in many cultures (Vincent, 2012). As explained by the UNICEF's quality analysis report in Turkey, in the developing business world, the number of women who are occupied with any work has increased in recent years and this increase has made early years foundation institutions very important. This foundation's interest is not only in children's education but also children's care and therefore, it is become significant that parental partnership is valuable for EYE (UNICEF, 2011). In Turkish society, women have taken over the child-related responsibilities. Despite the fact that, according to Secer, Ogelman and Onder (2013)'s research which analyses fathers' involvement in the preschools that fathers' involvement in the Turkish preschool has been sorted out 
very limited. There might be balance between mothers' and fathers' participation in the EYE and also suggesting the necessity of "father training programmes" (Secer et al., 2013, p. 70-71).

Likewise, the importance of the significant role of Turkish women in issues involving early childhood development has also been recognised in Ulger and Ulger's (2011) study of 293 mothers' role in allowing or limiting their children's decision-making powers regarding nutritional input. Bekman, Aksu-Koc, and Erguvanli-Taylan's (2011) investigation of the effectiveness of a 10-week early intervention programme deals with children from disadvantaged and multi-lingual backgrounds and was aimed at their language, preliteracy and pre-numeracy skills. While they do note a short-term improvement given the Pre-School Programme, they go out of their way to underline the importance of mothers' educational levels on 5-6-yearold children's literacy ability and vocabulary development, which was particularly evident when they were exposed to 'story time' activities (2011, p. 426-427). What both the Ulger and Ulger (2011) and Bekman et al. (2011) studies demonstrate is a keen awareness in the Turkish literature of the complex and interwoven role of family and structured formal environments for early childhood development.

Parents might have an active relationship with early childhood educators and should take their place in making early childhood education more effective. Parents should have the opportunity to explain their feelings, worries, concerns, expectations, and needs in regard to their children (Davis et al., 2002). Knowing these points and implementing them when early childhood educators are interacting with parents could prevent conflicts and provide for healthy communication, and parent- early childhood educator relationships must not be built on complaints about a teacher's qualification or their children's behaviour (Tezel Sahin and Unver, 2005). Their interactions might be better focussed not just on negative perceptions of each other but they should work together in order to contribute children's education and development and to solving problems about children, parenthood or schooling (Balkis, 2006). Being successful in supporting and helping parents depends on early childhood educators' skills and qualities and they need to understand the main issue and helping the process (Davis et al., 2002). Early childhood educators must respect family differences and try to understand their different backgrounds (Omeroglu and Can Yasar, 2005). If they do not consider this point important, it could result in preventing parent and educator collaboration in the early years (Atabey, 2008). Knowing what the parents want is likely to make the relationship between parents and early childhood educators easier (Davis et al., 2002).

The Turkish Educational Organisation has researched teachers' perspectives on parental involvement in preschool and elementary education, and in its analysis of the problems and solutions offered by Turkish early years early childhood educators invariably stated that their relationships with parents are very good (TED, 2007). However, the 2011 Education Monitoring Report, which was prepared by the group Education Reform Attempt, showed that the arrangements have been made quite rudimentarily (Egitim Reformu Girisimi [ERG], 2012). Teachers have the capacity to help parents to reach their goals and they stated that this should be used as part of their plan. As other commentators have noted, when parental involvement is being planned, it should not be forgotten that supporting early childhood education at home is necessary to gain a lasting effect and this point makes parental partnership important (Tezel Sahin and Unver, 2005). Parental partnership helps to provide continuity between school and home; it allows children to reinforce what they have learnt at school. In this way teachers and parents can help each other (Temel and Kurtulmus, 2010). Being involved with school is hard for working parents. As Vincent (2012) has underlined, some convenient solutions should be considered such as evening meetings with parents, otherwise, the level of relationship between early childhood educators and parents can be lower. Additionally, in Turkish context, some reviews have noted that parental involvement and the enlightenment of parents are important for providing a quality early childhood education (Bekman, 2002; Oktay, 2004).

Parents and early childhood educators have an important role in the EYE, and parent- early childhood educator relationships help early childhood educators to reach their educational targets in the curriculum (Atabey, 2008). The early childhood educators are seen as professionals who want to help regarding early years children (Isik, 2007). However, Kaya (2007) found that although teachers are well trained in teaching and in knowledge of the development of specific age groups of students, if parents do not support the teachers 
their work can be unsatisfying. Tok (2011, p. 94) has suggested that attitudes in pre-service primary education teachers were negatively impacted on the nature of their training, arguing that 'the courses need to be designed to encourage active participation and allow practice'. It is precisely this issue which could be transferred to the role of Turkish parents in EYE and development, particularly given the lack of training models or programmes, as some critics have noted with regard to fathers (Secer et al., 2013).

As an early childhood educator who interested in family involvement throughout my profession in Turkey, from my own observation, some teachers exclude the role of parents and they do not facilitate parents explaining their ideas or discussing problems they might be facing. This undesirable behaviour of teachers must be overcome and they should not forget that instead of excluding parents, it must be accepted that if EYE is supported at home, it could have a lasting impact on children's lives (Atabey, 2008). Davis et al. (2002) rightly outlined that early childhood educators have a valuable role in working with families to encourage healthy parent-child interaction, reinforce their skills to manage their desires and stresses of parenthood. In addition, there is an increasing acknowledgement in the literature on complex role of parents in early childhood development in Turkey (Ogelman and Seven, 2012; Oneren Sendil and Tantekin Erden, 2013; Unusan and Sanlier, 2007), and Kucuker's (2007, p. 338) study on family focused early intervention programmes designed to deal with developmental disabilities through parental training has argued that "in Turkey one could easily state that the formal support services are limited but informal social support services are not". Kucuker has also been crucial in acknowledging the stresses and pressures that Turkish parents are subject to, and through an investigation of 29 mothers and 28 fathers has traced the efficacy of a Small Steps Early Intervention Program which has been introduced in Turkey since 1996, and its role in reducing parental stress, an indication of an awareness both of the role of parents and an acknowledgement of the pressures they come under in relation to their offspring during the early childhood years.

A quality relationship between parents and early childhood educators entails professionalism on the part of teachers to encourage parental opinions, questions and conflicts (Vincent, 2012). Early childhood educators might talk about their observation in the class like children's participation in the classroom activities, communication with their peers and they can ask the parents about their observations on the home environment (Atabey, 2008). An early childhood educator could warmly encourage parents to share their opinions or their questions about their children. In this way information relevant to children could be a useful practice (Davis et al., 2002; Isik, 2007; Kaya, 2007). During this exchange of ideas about children it could be understood that parents might need gentle advice and assistance to improve and help their children's development or learning dispositions, and this has also been acknowledged in Turkish sources (Bekman, 2002; Kucuker, 2007; Unusan \& Sanlier, 2007). Following on from this, the Turkish literature has also underlined how they could work together to improve the child's learning and experiences (Aral, Kandir, and Can Yasar, 2002).

Parents have more information about their children because of spending more time with them at the home (Kaya, 2007). Hence, the early childhood educator should allow parents to clarify their concerns or worries and explore their trouble in order to enable the well-being of their children. This is the main stage to help solve parents' problems (Davis et al., 2002). However, working parents have limited time to take an interest in their children's school and this situation makes parental partnership difficult in the early years (Isik, 2007). As Bekman (2002, p. 124) has mentioned in the context of a four-year longitudinal research project on children and adults in three different contexts; educational, custodial and home care, "family networks are not as extended as before [therefore] the quality of centre-based child care services gains importance". While the nature of Turkish society is thriving educationally, parents' forums could be a useful method to encourage the participation of parents in the school activities, and in turn, could support parent- early childhood educator communication.

\section{Parenthood implications within the Turkish policy and Turkish pre-school education curriculum}

Parent involvement has been placed in the Turkish Pre-school Education Curriculum in 1994, 2002 and 2006. The first preschool education curriculum in Turkey was published in 1994, and it has been revised and 
improved in 2002 and 2006 respectively. 1994 version of Turkish Pre-school Education Curriculum included some encouragement activities such as parenthood education in the early years, newsletters, a news corner about the school, a suggestion box, individual meetings with parents, educational visits, and the provision of an end of the academic year report about their children. 2002 version of Turkish Pre-school Education Curriculum suggested that the early childhood educators should visit each child's home at least twice in an academic year and aimed learning about child's home environment and family atmosphere in the early years. In 2006's curriculum discussed these parental involvement activities: parenthood education activities, parentchild communication activities, individual interviews with parents, meetings, participation of school managements and giving parents a voice in decisions about school rules and programmes (MEB, 1994, 2002, 2006).

The importance of parental partnership in education also has been considered in the Council of National Education over the years. The first consideration in relation to early years took place in the third council meeting which was organized in 1946. In this council it was decided to inform parents about educational principles and also to encourage parental partnership with early childhood educators (CNE, 1946). The second consideration about the same topic was discussed in the ninth Council of National Education meeting in 1974 which emphasized the importance of parents' and early childhood educators' collaboration (CNE, 1974). For the third time, the issue was addressed in the eleventh council meeting in 1982 which debated teachers' roles in parental involvement. In accordance with this meeting, teachers were responsible for initiating the communication with parents and showing possible ways to solve problems which could be faced in the early childhood (CNE, 1982). The fourth time, the issue was discussed in the twelfth council meeting in 1988. In this meeting it was suggested that relationship with parents should be of higher quality and consistency (CNE, 1988). The fourteenth council in 1993 and the fifteenth in 1996 suggested making widespread "the school for mother and father" to inform parents about early childhood education and also implementing more programmes on parent involvement (CNE, 1993; 1996). The last council held in 2010 put forward that the psychological counselling and guidance services should be in contact with parents from pre-school education to higher education institute in regard to their children's problems during the compulsory education progress (CNE, 2010). Although there are some issues about the roles of both parties which need to be clarified, clear messages have come from the councils regarding the curriculum and how parents and early childhood educators can work in collaboration.

In 2002, an official Turkish report titled "School-Family Collaboration" was published. The purpose of this mandate was to inform teachers and schools about ways of interacting with parents when discussing the academic success and developmental levels of the children, in both public and private pre-schools, and suggested holding parents' meetings at least two times in each semester, how to prepare for these meetings and what to talk about in (Mandate of Family-School Collaboration, 2002). In 2004, a mandate titled "Regulation on Pre-school Education Institution" was published. The aim of this regulation is to define the management, education, establishment and duties of state and private preschools. This regulation also defined principles of EYE one of which is related to parental partnership in the early childhood period. Parents must join the meetings and if they wish, they can get more detailed information about their children's school performance from their teachers. According to this mandate different family backgrounds and socio-economic status will be considered by the school management (Mandate of Pre-school Education Institution Regulation, 2004).

The first parental involvement programme in Turkey was developed by Akkok, Ogeturk and Kokdemir in 1998 and conducted at Ankara Private Primary school by involving parents in the improvement of student self-esteem as well as social and academic development. In this study parents were informed about their children's developmental activities as carried out in the classroom and how to help their children at home, all over an academic year. The programme developers' purpose was to increase parent collaboration in schools and develop parent involvement programmes for the Turkish educational system. The researchers developed some strategies to raise parental involvement and introduced communication notebooks, home activities, parent meetings, newsletters and an informative leaflet about children's development to parents whose 
children were in pre-school and primary school. At the end of the programme parents and teachers were asked to evaluate it. Parents indicated that after the programme they felt more equipped in relation to child care, education, the understanding of their children and parenting skills. Teachers reported that through the programme there was an increasing relationship between parents and teachers and also, they had gained more experience in how to communicate with students and their parents (Akkok et al., 1998).

Collaboration between early years early childhood educators and parents paves the way to high quality EYE (Ari, 2005). However, there are some disadvantages in the use of some methods in the early years and have been the cause of conflicts in the early years foundations, particularly given differences in family backgrounds, parents' culture and social and economic variations. Also, according to the Turkish Prime Ministry State Planning Organization Department, families who live in some rural areas in Turkey, are increasingly badly behaved and neglectful about their children's academic situation and involvement in their school activities because of social, cultural and economic background differences (State Planning Organization Department [DPT], 2010).

In contrast to the dilemma of differences, Tezel Sahin and Ozyurek (2010) positively highlight the fact that sending a letter or a newsletter about the school activities to parents can be helpful to provide parent involvement in the early years and this is the responsibility of early years early childhood educators. However, there are also noticeable disadvantages for people in specific situations such as lone parents, parents from a different culture may not want to or be able to join in the social activities or parents' meetings at the schools (Roker and Coleman, 2007). Therefore, parents should be known individually by early childhood educators and they could be provided with specific information letters or meetings specifically for such parents could be organised. As Siraj-Blatchford has suggested, knowing parents' cultural backgrounds or specific needs could be helpful to build a relationship with parents in the EYE (Siraj-Blatchford, 1998).

When the literature on Turkish education has been analysed, within the Turkish Pre-School Education Curriculum and policy guidance, it can be concluded that many studies have been conducted to understand the issues of parental partnership in education which is a vital component for the success of children at their school (Ogelman and Seven, 2012; Oneren Sendil and Tantekin Erden, 2013; Unusan and Sanlier, 2007). In the last twenty years, some of the Turkish policy documents and studies have positively noted that parental partnership is important, when it applied in private and state research pre-schools where provides early childhood education (ACEV, 2011, Aral et al., 2002; Bekman, 2002; CNE, 2014; Inal, 2006; Isik, 2007; Kaya, 2007; MEB, 2006; Oktay, 2004; TED, 2007). These important outcomes include increasing children's academic achievement, improving children's creativity, healthy parents and children and early childhood educators' communication, increasing children's social, emotional, personal, cognitive, language and physical developments, promoting school readiness (Atabey, 2008; Gursimsek, Girgen, Harmanli, and Ekinci 2002; Inal, 2006; Isik, 2007; Omeroglu and Can Yasar, 2002; Sevinc and Evirgen, 2003; Tezel Sahin and Inal, 2007).

Involving parents in the education of their children also affects some developmental areas such as the social-psychological development of children in the early years (Gursimsek, 2003). The parental partnership also influences students' motivation at school and it raises the attendance rate (Sheldon, 2007). Parents get support for parenting and gain knowledge and developmental skills; they learn important points about child rearing practices and as a consequence of this practices and having more information about it increases their self-esteem (Gestwicki, 2004). Early childhood educators have an intrinsic role in exploring the experience, meaning and implications of the activities with the parent (Davis et al., 2002). However, in spite of the fact that all of these positive outcomes for the parents are known, there are also some studies indicating that although teachers try to involve parents, parents are unwilling to involve (Gursimsek et al., 2002; Kaya, 2007).

On the one hand, from the teachers' perspective, arrangements involving parents are time-consuming and tedious (Aral et al., 2002; Isik, 2007). According to Hoover-Demsey, Walker, Jones and Reed (2002), teachers are reluctant to establish partnerships since they had problems related to pragmatic, psychological, cultural issues and family involvement practices. To prevent these problems, there can be planned in-service training programmes by the policy-makers (Isik, 2007). Parental partnership provides benefits not only to parents and 
their children, but also for teachers. Even though mentioned issues and conflicts in the essay, Kaya (2007), Isik (2007) and Oktay (2002) convincingly stated that teachers' confidence increased because of their positive feedback from parents about their work with children, which is why the collaboration of parents and early childhood educators is important in EYE and this might be used effectively in the current Turkish early childhood policy.

\section{Conclusion}

In this critical examination, it has been highlighted that the relationship between Turkish parents and teachers in the early years settings could have many advantages. The benefits which derive from collaboration between parents and staff in the early years have also been argued and it has been stressed that early childhood educators need to give consideration to the parent's role in the home environment and school, and what early childhood educators' roles are in parental partnership. The relationship with both parents might be included by the early childhood educators in EYE to provide quality education and a form of equality in the partnership. Specifically, teachers are vital to help to remove the barriers by conducting well designed parental partnership programmes and they can provide parents with considerable information to use at home when they are spending quality time with their children (Kaya, 2007). The interaction between parents and children brings positive outcomes, for example, in social and emotional development and cognitive development (Ozyurek, 2004). These affirmative outcomes which are provided by parents are important to equip children for social involvement (Tezel Sahin and Ozyurek, 2010). Hence, it should be known that parental support is necessary for the early years. Turkish policy documents underline that parents have a crucial role in their children's development, that it is essential that they should be encouraged in their roles and that opportunities must be provided by early childhood educators for a successful partnership between parents and families (ACEV, 2011; MEB, 2006; TED, 2007; UNICEF, 2011), the importance of effective collaborations between parents and educators has been emphasised in the Turkish Pre-school Education Curriculum (MEB, 2006). Given all of this, the Turkish Pre-school Education Curriculum could be developed in order to provide more quality EYE with parental partnership in education, which much of the international and Turkish literature underlines as an issue of key importance Turkish policy documents and research has emphasised many times that parental involvement is an important element in the early years. Parents and early childhood educators need to be aware of their responsibilities to gain more benefit from the EYE of their children. Raising parents' awareness of early childhood education is of benefit for their children, while also necessary to improve the quality of policy for preschool institutions (Kapci and Guler, 1999). If the field of formal education and the family homes manage to speak to one another, it can only result in a more complete early childhood for Turkish children. In this manner, Turkish Pre-school Education Curriculum can be established in order to provide more quality early childhood education with parental partnership in education.

\section{Declarations}

Authors' contributions: The review has been written only by the author.

Ethics committee approval: The release permission has been taken from the Institute of Education UCL, Early Years Education MA programme leader.

Competing interests: There is no competing interests.

Funding: This review prepared as a part of an assessment of Early Years Education MA programme at the Institute of Education, UCL. The author would kindly thanks to Dr. Guy Roberts-Holmes for his contributions who is the programme conductor.

\section{References}

Akkok, F., Ogeturk, B., \& Kokdemir H. (1998). Ilkogretimde aile katilimi [Family involvement in Primary Schools]. TED Ankara College Education Journal, 97-98, 1(1), 14-17.

Allen, G. (2011). Early intervention: The next steps. London: Cabinet Office. 
Anne Cocuk Egitim Vakfi [Mother-Child Education Foundation]. (1999). Aile-cocuk Egitim Projesi [ParentYoung Children Education Project]. Retrieved from http://www.acev.org/ne-yapiyoruz/cocuklar-icin

Anne Çocuk Eğitim Vakfi [Mother-Child Education Foundation]. (2011). 2010- 2011 faaliyet raporu [Activity Report 2010 - 2011]. Retrieved from https://www.acev.org/wpcontent/uploads/2017/11/2010_2011_faaliyet_raporu.pdf

Aral, N., Kandir, A., \& Can Yasar, M. (2002). Okul oncesi egitim ve okul oncesi egitim programi [Preschool Education and Preschool Education Curriculum]. Ankara: YA-PA Publication.

Ari, M. (2005). Turkiye'de erken cocukluk egitimi ve kalitenin onemi [The importance of early childhood education and the quality of the education: New approaches in child development and education]. In M. Sevinc (Ed.), The new perspectives in development and education [Gelisim ve egitimde yeni yaklasimlar). Istanbul: Morpa Kultur Publications.

Atabey, D. (2008). Yonetici ogretmen aile isbirligi araci gecerlilik ve guvenirlik calisması ve okul oncesi egitim kurumlarindaki yonetici, ogretmenler ile aileler arasindaki iletisim ve isbirliginin yonetici, ogretmen, aile bakis acisina gore incelenmesi [Manager-teacher-family communication and coorperation tools, validity reliability study and examination of the communication and co-operation between managers, teacher, families in preschool organizations from the perspective of manager-teacher-family] (Master dissertation). Gazi University, Ankara.

Balkis, R. (2006). Okul-aile (cevre) iliskisi [Parent-teacher relations]. Science and Wisdom Education Journal (Bilim ve Aklin Aydinliginda Egitim Dergisi), 71, 24-25.

Bekman, S. (2002). Does daycare centre experience and it's aim matter?. European Early Childhood Education Research Journal, 10(1), 123-135.

Bekman, S., Aksu-Koc, A., \& Erguvanl1-Taylan, E. (2011). Effectiveness of an intervention program for sixyear-olds: A summer-school model. European Early Childhood Education Research Journal, 19(4), 409-431.

Berger, E. H. (2004). Parents as partners in education. Families and schools working together. Ohio: Pearson Prentice Hall.

Bogazici Universitesi Sosyal Politika Forumu [Bogazici Social Policy Forum]. (2009). Turkiye'de cocuk bakim hizmetlerinin yayginlastirilmasina yonelik bir oneri: Mahalle kresleri [A proposal for the improvement of childcare facilities in Turkey: Neighborhood nurseries]. Retrieved from http://www.spf.boun.edu.tr/docs/MAHALLE\%20KRESLERI\%20-\%20ARASTIRMA\%20RAPORU.pdf

Central Advisory Council of England. (1967). Children and their primary schools: The Plowden Report. London: HMSO.

Council of National Education. (1946). Third Council [III. Millî Eğitim Şûrası]. Retrieved from http://ttkb.meb.gov.tr/meb_iys_dosyalar/2017_09/29164646_3_sura.pdf

Council of National Education. (1974). Ninth Council [IX. Millî Eğitim Şûrası]. Retrieved from http://ttkb.meb.gov.tr/meb_iys_dosyalar/2017_09/29165045_9_sura.pdf

Council of National Education. (1982). Eleventh Council [XI. Millî Eğitim Şûrası]. Retrieved from http://ttkb.meb.gov.tr/meb_iys_dosyalar/2017_09/29165200_11_sura.pdf

Council of National Education. (1988). Twelfth Council [XII. Millî Eğitim Şûrası]. Retrieved from http://ttkb.meb.gov.tr/meb_iys_dosyalar/2017_09/29165252_12_sura.pdf

Council of National Education. (1993). Fourteenth Council [XIV. Millî Eğitim Şûrası]. Retrieved from http://ttkb.meb.gov.tr/meb_iys_dosyalar/2017_09/29165401_14_sura.pdf

Council of National Education. (1996). Fifteenth Council [XV. Millî Eğitim Şûrası]. Retrieved from http://ttkb.meb.gov.tr/meb_iys_dosyalar/2017_09/29165430_15_sura.pdf 
Council of National Education. (2010). Eighteenth Council [XVII. Millî Eğitim Şûrası]. Retrieved from http://ttkb.meb.gov.tr/meb_iys_dosyalar/2017_09/29170222_18_sura.pdf

Davis, H., Day, C., \& Bidmead, C. (2002). Working in partnership with parents: The Parent Adviser Model. London: Harcourt Assessment.

Department for Education. (2017). Statutory framework for the early years foundation stage setting the standarts for learning, development and care for children from birth to five. Retrieved from https://www.foundationyears.org.uk/files/2017/03/EYFS_STATUTORY_FRAMEWORK_2017.pdf

Devlet Planlama Teskilati [State Planning Organization]. (2010). Bin yil kalkinma hedefleri raporu [Millennium $\begin{array}{llll}\text { Development Goals Report]. } & \text { Retrieved }\end{array}$ http://planipolis.iiep.unesco.org/upload/Turkey/Turkey_MDG_2010_turkish.pdf

Divrengi, M., \& Aktan, E. (2011). Early childhood education in Turkey: Pre-school teachers' attitudes towards diversity. Journal of Peace Education, 8(1), 37-53.

Early Years Foundation Stage. (2012). Department for education. Retrieved from https://foundationyears.org.uk/files/2012/03/Development-Matters-FINAL-PRINT-AMENDED.pdf

Egitim Reformu Girisimi [Education Reform Initiative]. (2012). Egitim izleme raporu 2011 [Education Monitoring Report in 2011]. Istanbul Sabanci University, Istanbul.

Gestwicki, C. (2004). Home, school and community relations (5th ed.). USA: Delmar Learning.

Gol-Guven, M. (2009). Evaluation of the quality of early childhood classrooms in Turkey. Early Child Development and Care, 179(4), 437-451.

Gursimsek, I. (2003). Family involvement and social development in early childhood. Educational Sciences: Theory and Practice, 3(1), 140-144.

Gursimsek, I., Girgen, G., Harmanli, Z., \& Ekinci, Z (2002). Cocugun egitiminde aile katiliminin onemi (Bir pilot calisma) [The importance of parental participation in child education (Pilot study)]. Erken Cocukluk Gelisimi ve Egitimi Sempozyumu Bildiri Kitabı [Early Child Development and Education Symposium Reports]. Ankara: Kök Yayıncılık.

Hakyemez, S. (2015). Turkish early childhood educators on parental involvement. European Educational Research Journal, 14(1), 100-112.

Holzman, L. (2009). Vygotsky at work and play. New York: Routledge.

Hoover-Dempsey, K. V., Walker, J. M., Jones, K. P., \& Reed, R. P. (2002). Teachers Involving Parents (TIP): An in-service teacher education program for enhancing parental involvement. Teaching and Teacher Education, 18(7), 843-867.

Inal, G. (2006). Ogretmenlerin anaokullari ile anasiniflarindaki programlara aile katilimi konusundaki gorüslerin degerlendirilmesi (Afyon ili ornegi) [The evaluation of teachers' perspective on parental involvement (City of Afyon pilot study)] (Master dissertation). Hacettepe University, Ankara.

Isik, H. (2007). Okul oncesi egitim kurumlarında gerceklestirilen okul- aile isbirligi calismalarinin anne- baba goruslerine dayali olarak incelenmesi [Study of parent-school collaboration as implemented in preschool education institutions on the basis of parent's opinions] (Master dissertation). Anadolu University, Eskisehir.

Kapci, E. G., \& Guler, D. (1999). Pre-school education in Turkey: Policies and practices in their historical context. Early Child Development and Care, 156(1), 53-62.

Kaya, R. (2007). Okul oncesi ogretmenlerinin aile katilimlari ile ilgili tutumlari [The attitudes of pre-school teachers towards parental involvement] (Master dissertation). Middle East Technical University, Ankara.

Kucuker, S. (2007). The family-focused early intervention programme: Evaluation of parental stress and 
depression. Early Child Development and Care, 176(3), 329-341.

Mandate of Family - School Collaboration. (2002). Retrieved from http://orgm.meb.gov.tr./mevzuatlar/genelgeler/27OKULaileisbirligi.htm

Mandate of Pre-school Education Institution Regulation. (2004). Retrieved from http://mevzuat.meb.gov.tr/html/25486_html

Milli Egitim Bakanligi [Ministry of National Education]. (1994). Anasinifi programi (61-72) [Pre-school Curriculum for 61-72-month-old children]. Istanbul: National Education Press.

Milli Egitim Bakanligi [Ministry of National Education]. (2002). 36- 72 aylik cocuklar icin okul oncesi egitim programi [The curriculum for children aged 36-72 months]. Istanbul: Ya-Pa.

Milli Egitim Bakanligi [Ministry of National Education]. (2006). 36- 72 aylik cocuklar icin okul oncesi egitim programi [The curriculum for children aged 36-72 months]. Istanbul: Ya-Pa.

Milli Egitim Bakanligi [Ministry of National Education]. (2013). Okul öncesi egitim programi [Pre-school Education Programme]. Retrieved from http://tegm.meb.gov.tr/dosya/okuloncesi/ooproram.pdf

Ogelman, H. G., \& Seven, S. (2012). The effect social information processing in six-year-old children has on their social competence and peer relationships. Early Child Development and Care, 182(12), 1623-1643.

Oktay, A. (2004). Yasamin sihirli yillari: Okul oncesi donem [The Magic Years of The Life: Preschool Period]. Istanbul: Epsilon

Omeroglu, E., \& Can Yasar, M. (2002). Ev merkezli aile cocuk egitimi programinin ev ortamina etkisi [Homecentered parental involvement's affect on the home environment] Erken Cocukluk Gelisimi ve Egitimi Sempozyumu Notlari [Early Childhood Development and Education Symposium Notes]. Ankara: Kök Yayincilik, 34-49.

Omeroglu, E., \& Can Yasar, M. (2005). Okul öncesi egitim kurumlarında ailenin egitime katilimi [The participation of families in preschool education], Science and Wisdom Education Journal (Bilim ve Aklin Aydinliginda Egitim Dergisi), 62, 22-27.

Oneren Sendil, C., \& Tantekin Erden, F. (2013). Peer preference: A way of evaluating social competence and behavioural well-being in early childhood. Early Child Development and Care, 1(17), 230-246.

Organisation for Economic Co-operation and Development. (2012). Let's read them a story! The parent factor in education. Paris: OECD Publications.

Ozyurek, A. (2004). Kirsal bolge ve sehir merkezinde yasayan 5-6 yas grubu cocuga anne babalarn cocuk yetistirme tutumlarinin incelenmesi [Researching the attitudes of parents with children aged 5-6 years in the city-centre and countryside] (Master dissertation). Gazi University, Ankara.

Pelletier, J., \& Brent, J. (2002). Parent participation in children' school readiness: The effects of parental selfefficacy, cultural diversity and teacher strategies. International Journal of Early Childhood, 34(1), 45-60.

Rogoff, B. (1990). Apprenticeship in thinking: Cognitive development in social context. Oxford, England: Oxford University Press.

Roker, D., \& Coleman, J. (2007). Parenting young people: Research, policy and practice. In D. Roker and J. Coleman (Eds.), Working with parents of young people. London: Jessica Kingsley Publishers.

Secer, Z., Ogelman, G. H., \& Onder, A. (2013). The analysis of the relationship between fathers' parenting selfefficacy and the peer relations of preschool children. Early Child Development and Care, 183(1), 63-74.

Sevinc, M., \& Evirgen, S. (2003). Kucukcekmece okul oncesi egitim merkezinde verilen okul destekli anne egitim programinin anneler uzerindeki etkileri. Omep Dunya Konsey Toplantisi ve Konferansi Bildiri Kitabi2. Ankara: YA-PA Yayinlari. 
Sheldon, S. B. (2007). Improving student attandance with school, family and community partnerships. The Journal of Educational Research, 100(5), 267-275.

Siraj-Blatchford, I. (1998). A curriculum development handbook for early childhood educators. Staffordshire: Trentham Books.

Sy, S. R., Gottfried, A. W., \& Gottfried, A. E. (2013). A transitional model of parental involvement and children's achievement from early childhood through adolescence. Parenting: Science and Practice, 13(12), 133-152.

Temel, Z. F., \& Kurtulmus, Z. (2010). Aile egitimi ve erken cocukluk doneminde aile katilim calismalari [Family Involvement in the Early Childhood Period]. Ankara: Ani Publishing.

Tezel Sahin, F., \& Inal, G. (2007). Okul oncesi egitime aile katiliminin ogretmen ve okul uzerine etkisi [The effects of parental involvement on teachers and schools]. Egitimde Yeni Yonelimler Yapilandirmacilik ve Ogretmen, 4, 106- 110.

Tezel Sahin, F., \& Ozyurek, A. (2010). Anne baba egitimi ve okuloncesi aile katilimi [Mother-Father Education and Parental Involvement]. Ankara: Morpa Kultur.

Tezel Sahin, F., \& Unver, N. (2005). Okul oncesi egitim programlarina aile katilimi [Parental Involvement in Early Childhood Education]. Kastamonu Education Journal (Kastamonu Egitim Dergisi), 13(1), 23-30.

Tok, Ş. (2011). Pre-service primary education teachers' changing attitudes towards teaching: A longitudinal study. European Journal of Teacher Education, 34(1), 81-97.

Tokuc, H. (2007). Anne ve babalarin okuloncesi egitim hakkndaki gorus ve beklentilerinin incelenmesi [Research on the views and expectations of the parents concerning education in preschools] (Master dissertation). Hacettepe University, Ankara.

Turk Egitim Dernegi [Turkish Education Organisation]. (2007). Turkiye'de okuloncesi egitim ve ilkögretim sistemi temel sorunlar ve cozum onerileri [The problems of preschool and elementary education and their solutions]. Ankara: Adim Ajans.

Ulger, G., \& Ulger, B. (2011). Children in family purchase decision-making: Children's role in food product purchases from mothers' point of view. Journal of Marketing Communications, 18(4), 297-320.

United Nations International Children's Emergency Fund. (2011). Turkiye'de okul oncesi egitimde kalite standartlari durum analizi raporu [Report on quality of preschools, an analysis]. Retrieved from http://tegm.meb.gov.tr/erkenegitimisec/images/stories/duyurular/Kalite_durum_analizi_raporu_TR.pdf

Unusan, N., \& Sanlier, N. (2007). A Turkish perspective on nutrition education and preschool children. Early Child Development and Care, 177(8), 853-862.

Vincent, C. (2012). Parenting, responsibilities, risks and respect. London: Institute of Education, University of London.

Vygotsky, L. S. (1978). Mind in society: The development of higher psychological process. In M. Cole, V. John-Steiner, S. Scribner, and E. Souberman (Eds.). Cambridge: Harvard University Press. 